\title{
Efektivitas Implementasi Program Pemeliharaan Infrastruktur Jaringan Irigasi di Kabupaten Lebak
}

\author{
Ahmad Sururi \\ Program Studi Administrasi Publik Universitas Serang Raya \\ Email: ahmadbroer@gmail.com
}

Naskah diterima 24 Maret 2020, Revisi 30 Maret 2020, Terbit 19 April 2020

\begin{abstract}
Abstrak
DOI: doi.org/10.21107/pamator.v13i1.6949

Program pemeliharaan infrastruktur irigasi menjadi bagian penting terwujudnya pertanian yang berkelanjutan, dengan demikian pemeliharaan prasarana jaringan irigasi harus dilaksanakan secara rutin dan berkala guna menjaga terjadinya penurunan fungsi layanan jaringan irigasi. Metode penelitian menggunakan penelitian deskriptif dengan pendekatan kuantitatif dengan populasi sebanyak 59 responden dan teknik analisis data menggunakan uji validitas dan uji reliabilitas melalui piranti lunak Statistical Program Social Science (SPSS) versi 22. Pengujian uji T-Test dengan hipotesis pada penelitian ini yaitu hipotesis nol (Ho) kurang dari atau sama dengan ( $\leq$ ) 65\% dan Hipotesis Alternatifnya (Ha) lebih dari (>) 65\%, sehingga yang digunakan adalah uji pihak kanan. Hasil penelitian menunjukkan bahwa efektivitas implementasi program pemeliharaan infrastruktur irigasi di Kabupaten Lebak belum berjalan efektif karena mencapai angka 56\%, artinya angka tersebut kurang dari angka ideal yang diharapkan yaitu $65 \%$. Hasil diuji menunjukkan bahwa t-hitung jatuh pada penerimaan Ho dengan t-hitung $=-0,11$ dan t-tabel 0,678 sehingga dapat diketahui bahwa t-hitung lebih kecil dari pada t-tabel maka Ho diterima. Rekomendasi dalam penelitian ini adalah Pemerintah Kabupaten Lebak melalui Dinas PUPR Kabupaten Lebak harus meningkatkan lagi kualitas pemeliharaan jaringan irigasi dan bisa bermanfaat sesuai dengan fungsinya, peningkatan sumber daya aparatur dan penyelesaian pemeliharaan irigasi sesuai dengan SOP dan waktu yang sudah ditentukan.
\end{abstract}

Kata Kunci : efektivitas implementasi, program pemeliharaan irigasi

\begin{abstract}
Irrigation infrastructure maintenance program becomes an important part of the realization of sustainable agriculture, thus maintenance of irrigation network infrastructure must be carried out routinely and periodically in order to prevent the decline in the function of irrigation network services. The research method uses descriptive research with a quantitative approach with a population of 59 respondents and data analysis techniques using validity and reliability tests through Statistical Software Social Science (SPSS) version 22. T-Test testing with the hypothesis in this study is the null hypothesis ( Ho) is less than or equal to ( $\leq$ ) 65\% and the Alternative Hypothesis ( $\mathrm{Ha}$ ) is more than ( $>$ ) 65\%, so the right-side test is used. The results showed that the effectiveness of the implementation of irrigation infrastructure maintenance programs in Lebak Regency had not been effective because it reached 56\%, meaning that the figure was less than the expected ideal number of $65 \%$. Based on the results tested and analyzed by researchers, it is found that the $t$-count falls on the acceptance of Ho with $t$-count $=-0.11$ and $t$-table 0.678 so it can be seen that the $t$-count is smaller than the t-table then Ho be accepted. The recommendation in this study is that the Lebak Regency Government through the Lebak Regency PUPR Office should improve the quality of irrigation network maintenance again and be beneficial in accordance with its function, increasing apparatus resources and completing irrigation maintenance in accordance with the SOP and a predetermined time.
\end{abstract}

Keywords : effectiveness of implementation, irrigation maintenance program

\section{PENDAHULUAN}

Infrastruktur irigasi merupakan salah satu komponen pokok dalam proses produksi pangan khususnya dalam budidaya pertanian terutama di pedesaan. Berdasarkan Peraturan Pemerintah Nomor 20 Tahun 2006 tentang Pengelolaan
Jaringan Irigasi disebutkan bahwa jaringan irigasi adalah saluran, bangunan dan bangunan pelengkapnya yang merupakan satu kesatuan yang diperlukan untuk penyediaan, pembagian, pemberian, penggunaan dan pembuangan air irigasi. Fungsi dari irigasi sangat penting yaitu 
sebagai sarana untuk mencukupi ketersedian air untuk usahatani padi sawah (Pasandaran, 2016).

Secara operasional irigasi dibedakan kedalam tiga katagori yaitu jaringan irigasi primer, sekunder dan tersier. Dari ketiga kelompok jaringan tersebut, yang langsung berfungsi sebagai prasarana pelayanan air irigasi dalam petakan sawah adalah jaringan irigasi tersier yang terdiri dari saluran tersier, saluran kuarter dan saluran pembuang, boks tersier, boks kuarter serta bangunan pelengkap. Dengan demikian sistem pengelolaan dan pendayagunaan irigasi dilakukan untuk mendorong pemanfaatan air secara efekif. Pengelolaan infrastruktur irigasi untuk menunjang irigasi masa depan diperlukan untuk terlaksananya multifungsi pertanian yaitu terwujudnya proses diversifikasi pertanian secara meluas, meningkatnya fungsi konservasi sistem irigasi, dan terpeliharanya warisan nilai-nilai budaya berupa kearifan lokal dan kapital sosial dalam pengelolaan irigasi (Pasandaran, 2016). Hal tersebut dilakukan dikarenakan besarnya potensi kerusakan infrastruktur irigasi sebagai ujung tombak produktivitas pertanian dan ketahanan pangan. Beberapa penelitian tentang kebijakan infrastruktur irigasi sudah dilakukan oleh (Bria \& Sutirto, 2017) tentang analisis kriteria untuk perencanaan program pemeliharaan embung irigasi dan (Kusuma, 2018) tentang analisis dampak rehabilitasi jaringan irigasi tersier terhadap pendapatan petani di Kabupaten Aceh Besar, dalam hasil penelitiannya disebutkan bahwa bahwa dengan adanya rehabilitasi jaringan irigasi tersier memberikan dampak yang positif bagi petani dimana semakin baiknya jaringan irigasi maka penggunaan input produksi semakin rendah dan hasil produksi padi dan pendapatan petani makin meningkat pula. Kemudian penelitian oleh (Rismanto et al., 2013) mengemukakan dalam hasil penelitiannya bahwa Variabel Attitude Toward Behaviour (ATB), Subjective Norm (SN), dan Perceived Behaviour Control ( $P B C$ ) berpengaruh positif terhadap maksud petani dalam memilih turut berperan atau tidak dalam OP jaringan irigasi.

Penelitian yang dilakukan oleh (Rafi'ud et al., 2017) menyimpulkan terjadi penurunan efisiensi total saluran di Daerah Irigasi Boro menjadi 47,61\%. Nilai efisiensi riil ini jauh dari ideal efisiensi penyaluran irigasi yaitu 68,8\%, sedangkan (Puspitasari, 2014) dalam hasil penelitian menunjukkan bahwa pengalokasian pendanaan pada pemeliharaan rutin bersifat statis, dimana besarnya hampir sama setiap tahun sedangkan pada pendanaan pemeliharaan berkala bersifat dinamis yang selalu berubah setiap tahunnya sesuai kondisi eksisting di lapangan.

Kemudian menurut Peraturan Menteri Pekerjaan umum dan Perumahaan Rakyat No 12/PRT/M/2015 tentang Pedoman penyelenggaraan pemeliharaan jaringan irigasi, pemeliharaan irigasi adalah upaya menjaga dan mengamankan jaringan irigasi agar selalu dapat berfungsi dengan baik guna memperlancar pelaksanaan operasi dan mempertahankan kelestariannya melalui kegiatan perawatan, perbaikan, pencegahan dan penanganan yang harus dilakukan terus menerus. Dalam hal ini keberlanjutan pemeliharaan irigasi menjadi salah satu tujuan pembangunan berkelanjutan (Grigg, 2019).

Berdasarkan Peraturan Pemerintah nomor 20 Tahun 2006 dibagi dalam 3 (tiga) kriteria berdasarkan kewenangan yaitu : (1) Daerah Irigasi dengan Luas Areal $\geq 3000 \mathrm{Ha}$ merupakan Kewenangan Pemerintah Pusat; (2) Daerah Irigasi dengan Luas Areal 1000 Ha s/d < 3000 ha merupakan Kewenangan Pemerintah Provinsi; (3) Daerah Irigasi dengan Luas Areal < $1000 \mathrm{Ha}$ merupakan Kewenangan Pemerintah Kabupaten/Kota. Selain itu dari keseluruhan luas irigasi di Indonesia sekitar 7.2 juta $\mathrm{Ha}$, Pemerintah pusat hanya memiliki kewenangan pengelolaan dan pemeliharaan sekitar $28 \%$ dari jumlah keseluruhan luas irigasi dan sisanya adalah kewenangan dari Pemerintah daerah yakni Pemerintah Provinsi dan Kabupaten/Kota (Senin, 31 Juli 2017, www.pu.go.id). Sebagai motor utama terlaksananya pengelolaan jaringan irigasi yang baik maka prasarana jaringan (bangunan sadap/bagi/pemberi, saluran, bangunan pengatur dan pengukur air irigasi) harus siap dan dalam kondisi baik. Untuk itu pemeliharaan prasarana jaringan irigasi harus dilaksanakan secara rutin dan berkala guna menjaga terjadinya penurunan fungsi layanan jaringan irigasi.

Di Provinsi Banten terdapat 4 hulu sungai yang mengairi hampir seluruh wilayah di 
daerah Provinsi Banten. Ke-empat hulu sungai ini mengairi 152 aliran sungai yang tersebar di beberapa daerah. Tidak semua jaringan irigasi adalah kewenangan dari pemerintah daerah, seperti yang terdapat pada data di bawah ini bahwa luas daerah irigasi kewenangan pemerintah di Provinsi Banten sebanyak 62.209 Ha. Jumlah luas irigasi yang di kelola oleh pemerintah pusat lebih banyak dibandingkan dengan jumlah luas wilayah jaringan irigasi yang di kelola oleh Pemerintah Daerah Provinsi Banten sendiri. Luas Daerah irigasi kewenangan dari Provinsi Banten sebanyak 29.491 Ha, dan diantaranya terbagi kedalam 6 Daerah Irigasi antar lintas Kabupaten/Kota. Berikut adalah data wilayah sungai yang berada di Provinsi Banten.

Tabel 1. Wilayah Sungai di Provinsi Banten

\begin{tabular}{|c|c|c|c|c|}
\hline $\begin{array}{l}\mathbf{N} \\
\mathbf{O}\end{array}$ & Kode WS & Nama WS & $\begin{array}{c}\text { Jumlah } \\
\text { DAS }\end{array}$ & Provinsi \\
\hline 1 & 02.03.A2 & $\begin{array}{l}\text { Cidanau- } \\
\text { Ciujung- } \\
\text { Cidurian }\end{array}$ & 35 & Banten \\
\hline 2 & 02.05.A2 & $\begin{array}{l}\text { Ciliwung- } \\
\text { Cisadane }\end{array}$ & 15 & $\begin{array}{l}\text { Banten } \\
\text { Jakarta }\end{array}$ \\
\hline 3 & 02.01.B & $\begin{array}{l}\text { Cibaliung- } \\
\text { Cisawarna }\end{array}$ & 75 & Banten \\
\hline 4 & 02.02.B & $\begin{array}{l}\text { Ciliman- } \\
\text { Cibungur }\end{array}$ & 27 & Banten \\
\hline
\end{tabular}

Sumber: Bapedda Provinsi Banten, 2018

Kabupaten Lebak adalah wilayah yang terbanyak di lewati jaringan irigasi, berdasarkan data bahwa terdapat 29.491 Ha. Wilayah Kabupaten Lebak sebagian besar wilayahnya adalah dataran tinggi dan sebagian kecilnya berbatasan langsung dengan bibir pantai. Pemerintah Kabupaten Lebak beserta Dinas Pekerjaan Umum dan Perumahan Rakyat (PUPR) Kabupaten Lebak bekerjasama mengelola sektor Perairan dan irigasi di Kabupaten Lebak dalam hal ini Sub Bidang Yang mengelola adalah Sub Bidang Pengelolaan Sumber Daya Air. Di Kabupaten Lebak Perda yang mengatur mengenai perkembangan irigasi adalah Perda Kabupaten Lebak No 5 Tahun 2008 tentang Irigasi. Perda tersebut mengatur semua yang berkaitan dengan perairan dan irigasi baik itu dari pengelolaan maupun pemeliharaan. Sampai saat ini jaringan daerah irigasi tercatat sebanyak 474 unit yang terdiri dari 463 irigasi permukaan dan 11 irigasi pompa.
Tabel 2. Jumlah Daerah Irigasi (DI) di Kabupaten Lebak Menurut Jenisnya

\begin{tabular}{cccc}
\hline No & Jenis & Jumlah DI & Luas \\
\hline 1 & DI Permukaan & 463 & 49.264 \\
2 & DI Pompa & 11 & 1.283 \\
& Jumlah & $\mathbf{4 7 4}$ & $\mathbf{5 0 . 5 4 7}$ \\
\hline
\end{tabular}

Sumber: Bapedda Provinsi Banten, 2018

Dari data di atas menunjukan bahwa jumlah luas jaringan irigasi yang baerada di Kabupaten Lebak seluas $50.547 \mathrm{Ha}$. Meskipun demikian program pemeliharaan infrastruktur irigasi di Kabupaten Lebak masih menemui beberapa permasalahan seperti minimnya Sumber Daya Manusia yang memiliki kompetensi yang spesifik seperti bidang keilmuan teknik sipil, kurangnya pengawasan dan pengendalian dalam proses pemeliharaan irigasi, anggaran pemeliharaan yang belum memadai, masih kurangnya sarana dan prasarana untuk mendukung proses pemeliharaan. Kerusakan saluran irigasi di berbagai wilayah kurang mendapat perhatian pemerintah, baik pusat maupun daerah (Ardelimas ARS et al, 2016), akan tetapi disisi lain kehadiran jaringan irigasi mampu memberikan sumbangan besar terhadap program ketahanan pangan nasional dan kebutuhan kehidupan manusia baik itu di tingkat daerah maupun di lingkup pusat.

Pendekatan terintegrasi untuk analisis dan perencanaan yang diharapkan dapat menyeimbangkan biaya dan manfaat dan mengatasi prioritas yang dirasakan oleh semua pemangku kepentingan dalam pemeliharaan irigasi perlu terus dilakukan (Mollinga, 2013). Hal tersebut disebabkan karena pendekatan formil dalam pemeliharaan program irigasi perlu dibarengi dengan inovasi kebijakan lainnya (Alexander et al., 2015). Bahwa inovasi kebijakan publik sebagai sebuah keniscayaan secara prinsip dan substantif akan memberikan penguatan dalam merespon dan menyelesaikan problematika di tengah masyarakat termasuk dalam hal ini adalah program pemeliharaan irigasi di Kabupaten Lebak (Sururi, 2014). Tujuan penelitian ini adalah mengukur sejauhmana efektivitas implementasi program pemeliharaan infrasruktur irigasi di Kabupaten Lebak. 


\section{METODOLOGI}

Pendekatan dalam penelitian deskriptif dengan pendekatan kuantitatif yaitu penelitian untuk mendeskripsikan bagaimana efektivitas implementasi program pemeliharaan infrastruktur di Kabupaten Lebak. Adapun populasi dalam penelitian ini adalah seluruh pegawai pada Kantor Dinas Pekerjaan Umum dan Penataan Ruang (PUPR) Bidang Sumber daya manusia dan di UPTD wilayah $\mathrm{V}$ wilayah Lebak sebanyak 59 responden. Teknik analisis data menggunakan uji validitas dan uji reliabilitas melalui piranti lunak Statistical Program Social Science (SPSS) versi 22. Pengujian uji T-Test dengan rumus sebagai berikut :

Keterangan :

$$
\text { thitung }=\frac{X-\mu o}{\left(\frac{S D}{\sqrt{N}}\right)}
$$

$$
\begin{array}{ll}
\mathrm{t} & =\text { Nilai } \mathrm{t} \text { hitung } \\
\mathrm{x} & =\text { Rata-rata sampel } \\
\mu \mathrm{O} & =\text { Nilai yang dihipotesisikan } \\
\mathrm{SD} & =\text { Standar deviasi sampel } \\
\mathrm{N} & =\text { Jumlah sampel }
\end{array}
$$

Hipotesis pada penelitian ini yaitu hipotesis nol $\left(\mathrm{H}_{0}\right)$ kurang dari atau sama dengan $(\leq) 65 \%$. Hipotesis Alternatifnya $\left(\mathrm{H}_{\mathrm{a}}\right)$ lebih dari $(>) 65 \%$, sehingga yang digunakan adalah uji pihak kanan.

\section{HASIL PEMBAHASAN}

\section{Uji Validitas}

Uji validitas digunakan untuk mengukur sah atau valid tidaknya suatu kuisioner. Suatu kuisioner dikatakan valid jika penyataan pada kuisioner mampu untuk mengungkapkan sesuatu yang diukur oleh kuisioner tersebut. Pengujian validitas dalam penelitian ini menggunakan Pearson Correlation yaitu dengan cara menghitung korelasi antara nilai yang diperoleh dari pernyataan-pernyataan dengan bantuan software SPSS versi 22.

Tabel 3. Uji Validitas Efektivitas Pemeliharaan Irigasi

\begin{tabular}{ccccc}
\hline No & Pernyataan & $\begin{array}{c}\text { Nilai r } \\
\text { Tabel }\end{array}$ & $\begin{array}{c}\text { Nilai r } \\
\text { Htung }\end{array}$ & Kesimpulan \\
\hline 1 & Pernyataan 1 & 0,256 & 0,547 & Valid \\
2 & Pernyataan 2 & 0,256 & 0,547 & Valid \\
3 & Pernyataan 3 & 0,256 & 0,442 & Valid \\
4 & Pernyataan 4 & 0,256 & 0,400 & Valid \\
5 & Pernyataan 5 & 0,256 & 0,458 & Valid \\
6 & Pernyataan 6 & 0,256 & 0,391 & Valid
\end{tabular}

\begin{tabular}{ccccc}
\hline No & Pernyataan & $\begin{array}{c}\text { Nilai } r \\
\text { Tabel }\end{array}$ & $\begin{array}{c}\text { Nilai } r \\
\text { Htung }\end{array}$ & Kesimpulan \\
\hline 7 & Pernyataan 7 & 0,256 & 0,528 & Valid \\
8 & Pernyataan 8 & 0,256 & 0,353 & Valid \\
9 & Pernyataan 9 & 0,256 & 0,367 & Valid \\
10 & Pernyataan 10 & 0,256 & 0,306 & Valid \\
11 & Pernyataan 11 & 0,256 & 0,553 & Valid \\
12 & Pernyataan 12 & 0,256 & 0,375 & Valid \\
13 & Pernyataan 13 & 0,256 & 0,41 & Valid \\
14 & Pernyataan 14 & 0,256 & 0,273 & Valid \\
15 & Pernyataan 15 & 0,256 & 0,401 & Valid \\
16 & Pernyataan 16 & 0,256 & 0,530 & Valid \\
17 & Pernyataan 17 & 0,256 & 0,374 & Valid \\
18 & Pernyataan 18 & 0,256 & 0,321 & Valid \\
19 & Pernyataan 19 & 0,256 & 0,304 & Valid \\
20 & Pernyataan 20 & 0,256 & 0,355 & Valid \\
21 & Pernyataan 21 & 0,256 & 0,271 & Valid \\
22 & Pernyataan 22 & 0,256 & 0,291 & Valid \\
23 & Pernyataan 23 & 0,256 & 0,464 & Valid \\
24 & Pernyataan 24 & 0,256 & 0,289 & Valid \\
25 & Pernyataan 25 & 0,256 & 0,325 & Valid \\
\hline & Berdasarkan & 0601 di & atas, kriteria item \\
\hline
\end{tabular}

Berdasarkan tabel di atas, kriteria item atau butir instrument pada variable Efektivitas Pemeliharaan Irigasi adalah jika $r_{\text {hitung }}>r_{\text {tabel }}$, maka item atau butir instrument dinyatakan valid, sedangkan jika $r_{\text {hitung }}<r$ tabel maka dinyatakan tidak valid. Nilai $r_{\text {tabel }} d i$ dapatkan dari perhitungan $\mathrm{df}=\mathrm{n}-2=59-2=$ 57 dengan taraf signifikan 0.05 atau $5 \%$, maka didapatkan nilai $r$ sebesar 0.256 .

\section{Uji Realibilitas}

Kriteria pengujian instrumen dikatakan reliabel apabila $r_{\text {hitung }} \geq r_{\text {tabel }}$ pada taraf signifikasi $5 \%$. Jika instrumen reliabel berdasarkan uji coba, hasil perhitungan uji reliabilitas pada penelitian ini dapat diinterpretasikan sebagai berikut :

Tabel 4. Uji Realibilitas

Reliability Statistics

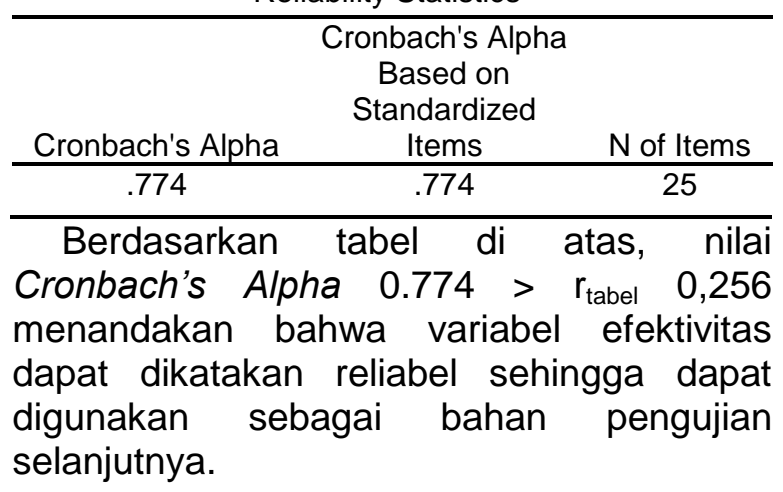




\section{Analisa Data}

Pada penelitian ini, data penelitian didapat dari hasil penyebaran kuisioner yang dilakukan kepada 59 yang terdiri dari 50 orang responden merupakan laki-laki dan 9 orang responden merupakan perempuan. Terdapat 5 pilihan jawaban dalam kuisioner, yaitu jawaban sangat setuju memiliki nilai 5, setuju memiliki nilai 4, ragu-ragu memiliki nilai 3 , tidak setuju memiliki nilai 2 dan sangat tidak setuju memiliki nilai 1. Hasil data yang telah didapat, diolah dan ditampilkan dalam bentuk diagram dan akan dipaparkan maksud dan kesimpulan dari tiap-tiap pernyataan.

\section{$\underline{\text { Uji Hipotesis }}$}

Hipotesis yang dipakai adalah besarnya efektivitas program pemeliharaan irigasi di Dinas Pekerjaan Umum dan Penataan Ruang (PUPR) Kabupaten Lebak , dimana peneliti memprediksi hipotesis minimal $65 \%$ dari nilai ideal yaitu $100 \%$, dengan penjelasan sebagai berikut :

$\mathrm{H}_{0}$ : Tingkat Efektivitas Program Pemeliharaan Irigasi Di Dinas Pekerjaan Umum Dan Penataan Ruang (PUPR) Di Kabupaten Lebak $\leq 65 \%$.

$\mathrm{H}_{\mathrm{a}}$ : Tingkat Efektivitas Program Pemeliharaan Irigasi Di Dinas Pekerjaan Umum Dan Penataan Ruang (PUPR) Di Kabupaten Lebak $>65 \%$.

Hipotesis ( $\mathrm{Ha}$ dan $\mathrm{Ho}$ ) model statistik:

$\mathrm{Ho}: \mu \leq 65 \%$ dan $\mathrm{Ha}: \mu>65 \%$

Pada penelitian yang dilakukan oleh peneliti, maka hipotesis yang peneliti prediksi adalah hipotesis "efektivitas program pemeliharaan irigasi di Dinas Pekerjaan Umum dan Penataan Ruang (PUPR) di Kabupaten Lebak kurang dari atau sama dengan $65 \%$ ( $\leq 65 \%)$ ". Pengujian hipotesis dimaksudkan untuk mengetahui tingkat signifikasi dari hipotesis yang diajukan. Berdasarkan metode penelitian, maka pada tahap pengujian hipotesis penelitian ini, peneliti menggunakan rumus $t_{\text {test }}$ satu sampel. Adapun perhitungan hipotesis tersebut yaitu sebagai berikut $5 \mathrm{x}$ $25 \times 59=7.375$. Berdasarkan data yang diperoleh, maka skor ideal yang diperoleh adalah $5 \times 25 \times 59=7.375$ ( $5=$ nilai skor ideal dari tiap jawaban responden, kriteria skor berdasarkan pada skala Likert, 25= jumlah pernyataan yang valid, $59=$ jumlah sampel yang dijadikan responden). Sedangkan untuk skor penelitian adalah sebesar 4.136.

Dengan demikian nilai efektivitas program pemeliharaan irigasi di Dinas Pekerjaan Umum dan Penataan Ruang (PUPR) adalah 4.136:7.375 $=0,560$ atau dalam presentase yaitu dibulatkan sebesar $56 \%$. Selanjutnya untuk menguji hipotesis maka peneliti menggunakan rumus $t_{\text {test }}$ satu sampel. Skor ideal untuk efektivitas program pemeliharaan irigasi di Dinas Pekerjaan Umum dan Penataan Ruang (PUPR) Kabupaten Lebak $5 \times 25 \times 59=7.375(5=$ nilai skor ideal dari tiap jawaban responden, kriteria skor berdasarkan pada skala Likert, $25=$ jumlah pernyataan yang valid, 59= jumlah sampel yang dijadikan responden), dan nilai mean atau rata-ratanya adalah 7.375 : $59=125$. efektivitas program pemeliharaan irigasi di Dinas Pekerjaan Umum dan Penataan Ruang (PUPR) di Kabupaten Lebak $56 \%$ dari yang diharapkan, nilai hipotesiskan 0,65 x 7.375: $59=81.25$. Hipotesis statistiknya dapat ditulis dengan rumus :

Ho $: \mu 0 \leq 65 \% \leq 0,65 \times 7.375: 59=81.25$

$\mathrm{Ha}: \mu \mathrm{a}>65 \%>0,65 \times 7.375: 59=81.25$

Berikut ini rumus uji $t_{\text {test }}$ satu sampel ialah sebagai berikut :

$\mu_{0}=81$

$$
\bar{X}=\left[\frac{4136}{59}\right]=70,10
$$

$\mathrm{SD}=7026$

$\mathrm{N}=59$

$$
\begin{gathered}
\mathrm{t}=\frac{X-\mu o}{\left(\frac{S D}{\sqrt{N}}\right)} \\
\mathrm{t}=\frac{70.10-81}{\left(\frac{7026}{\sqrt{59}}\right)} \\
\mathrm{t}=\frac{70,10-81}{\left(\frac{7026}{\sqrt{59}}\right)}=-, 011
\end{gathered}
$$

Harga $t_{\text {hitung tersebut selanjutnya }}$ dibandingkan dengan harga $t_{\text {tabel }}$ dengan derajat kebebasan $(\mathrm{dk})=\mathrm{n}-1=59-1=58$ dan taraf kesalahan $\alpha=5 \%$ untuk di uji satu pihak kanan maka harga $t_{\text {tabel }}$ yaitu 0,678 karena harga $t_{\text {hitung }}<t_{\text {tabel }} \quad(-0,11<0,678)$ dan jatuh pada penerimaan Ho, maka hipotesis nol (Ho) diterima dan hipotesis kerja $(\mathrm{Ha})$ ditolak. Harga ini dapat ditunjukan pada Gambar 2, harga terletak pada daerah 
penerimaan Ho. Berikut adalah gambar kurva daerah penerimaannya.

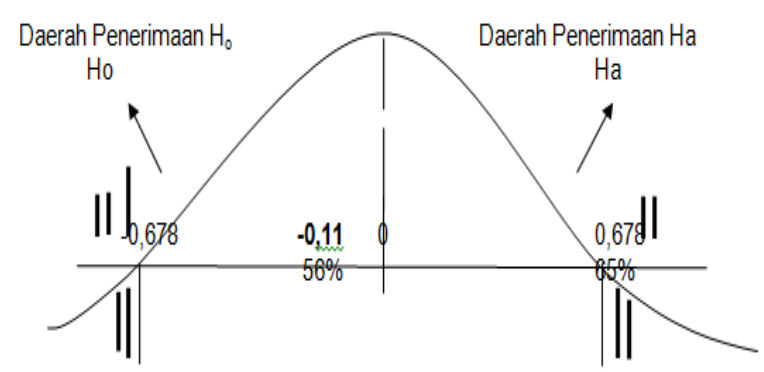

Gambar 1

Kurva Penolakan dan Penerimaan Uji Hipotesis Pihak Kanan

\section{Interpretasi Hasil Penelitian}

Peneliti akan menginterpretasikan data dari hasil pengamatan dengan penyebaran kuesioner dengan berdasarkan 25 butir pernyataan dan variabel efektivitas yang diajukan kepada 59 responden yaitu Dinas PUPR Kab Lebak wilayah V Kecamatan Malingping dan pekerja lapangan di wilayah $\mathrm{V}$ kecamatan Malingping. Berdasarkan hasil yang diperoleh dapat dikatakan bahwa Tingkat Efektivitas Program Pemeliharaan Irigasi di Dinas Pekerjaan Umum dan Penataan Ruang (PUPR) Di Kabupaten Lebak masih kurang baik, hal ini dibuktikan dengan jawaban responden atas variabel efektivitas. Dari hasil uji persyaratan statistic, skor ideal instrument pada variabel efektivitas adalah $5 \times 25 \times 59=7.375(5=$ nilai skor ideal dari tiap jawaban responden, kriteria skor berdasarkan pada skala Likert, 25 = jumlah pernyataan yang valid, $59=$ jumlah sampel yang dijadikan responden). Sedangkan untuk skor penelitian adalah sebesar 4.136.

Dengan demikian tingkat efektivitas program pemeliharaan irigasi di Dinas Pekerjaan Umum dan Penataan Ruang (PUPR) di Kabupaten Lebak adalah 4.136 : $7.375=0,560$ atau dalam presentase yaitu sebesar $56 \%$. Sehingga dapat diketahui bahwa $56 \%$ dan termasuk kurang baik atau kurang efektif. Data tersebut dapat dianalisis berdasarkan scoring jawaban dari responden. Berdasarkan skor yang telah dihitung di atas ditetapkan maka: Total skor ideal (kriterium) untuk seluruh item $=4.136$

Skor tertinggi $=5 \times 30 \times 59=7375$.

Skor terendah $=1 \times 25 \times 59=1475$
Kategori Instrumen:

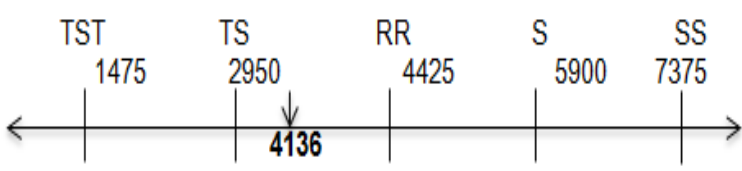

Gambar 2. Nilai Efektifitas Program

Pemeliharaan Irigasi PUPR Kabupaten Lebak

Sehingga hasil dari pengujian hipotesis tersebut dapat dijelaskan bahwa tingkat efektivitas program pemeliharaan irigasi di Dinas Pekerjaan Umum dan Penataan Ruang (PUPR) di Kabupaten Lebak mencapai angka 56\% dari angka minimal yang dihipotesiskan yaitu $65 \%$, dengan demikian tingkat efektivitas nya masih kurang efektif. Nilai 4136 termasuk dalam kategori interval "tidak setuju dan ragu-ragu" namun cenderung mendekati tidak setuju.

Dalam menguji hipotesis penelitian ini dilakukan dengan uji signifikasi $\alpha=0,05$. Kaidah pengujian jika $t_{\text {tabel }}>$ (lebih besar)

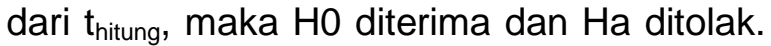
Jika $t_{\text {tabel }}<t_{\text {hitung }}$ maka $\mathrm{HO}$ ditolak, dan $\mathrm{Ha}$ diterima. Berdasarkan hasil yang diuji dan dianalisis maka yang di dapat adalah $t_{\text {hitung }}$ jatuh di penerimaan Ho dengan $t_{\text {hitung }}=-0,11$ dan t-tabel $=0,678$ sehingga dapat diketahui $t_{\text {tabel }}$ lebih besar dari pada $t_{\text {hitung }}$ maka Ho diterima.

Berdasarkan hasil uji validitas yang telah dilakukan, maka dapat diketahui bahwa seluruh instrument yang digunakan adalah valid, dimana $r^{-}$hitung lebih besar dari pada $r$ tabel yang dihasilkan dari rumus sebagai berikut:

$$
r=\frac{t}{\sqrt{d f+t^{2}}}
$$

Selanjutnya dalam melakukan uji reliabilitas dengan menggunakan rumus Alpha Cronbach maka didapat bahwa instrument pernyataan dinyatakan reliabel, karena nilai $0.774>r$ tabel 0.256 . Dimana suatu instrument penelitian dikatakan reliabel bila koefisien reliabilitas $>0.256$.

Dari pembahasan yang memaparkan tentang pengujian hipotesis menjelaskan bahwa Ho diterima dan Ha ditolak. Hasil uji hipotesis tersebut diperoleh dari nilai $t_{\text {hitung }} \leq$ $t_{\text {tabel }}(-0,11 \leq 0,678)$. Dari data tersebut dapat dijelaskan bahwa efektivitas program pemeliharaan irigasi di Dinas Pekerjaan Umum dan Penataan Ruang (PUPR) di 
Kabupaten Lebak dinilai ragu-ragu (kurang baik) yaitu mencapai angka $56 \%$. Hasil penelitian ini dapat melihat kembali pada teori yang digunakan pada penelitian ini. Dalam penelitian ini, peneliti menggunakan teori Efektivitas Organisasi menurut Gibson et al dalam Tangkilisan (2005), yaitu terdapat 7 indikator yang menjadi parameter Efektivitas dalam penelitian ini dengan uraian sebagai berikut :

\section{Kejelasan Tujuan yang Hendak Dicapai}

Dalam indikator proses analisis dan perumusan kebijakan yang mantap, terdapat 5 butir pernyataan. Dalam indikator ini nilai persentasenya mencapai $55,76 \%$, hasil tersebut diperoleh dari skor ideal dari indikator mengetahui dan aplikasi yakni $4 \mathrm{x}$ $5 \times 59=1180$. Kemudian dibagi dengan skor rill yang diisi oleh responden yaitu sebesar $658: 1180=0.4743 \times 100 \%=$ $55,76 \%$. Kategori instrumen indikator kejelasan tujuan yang hendak di capai :

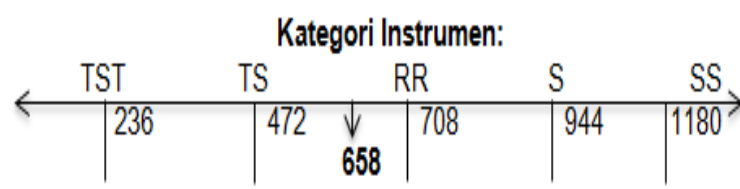

Gambar 3. Kategori Instrumen Tujuan

Dengan demikian, dapat dikatakan bahwa Kejelasan Tujuan Yang Hendak di Capai dalam pelaksanaan berada kategori interval "tidak setuju dan ragu-ragu". Hal ini dapat terlihat dari jawaban responden terhadap pernyataan yang diberikan.

\section{Kejelasan Strategi Pencapaian Tujuan}

Dalam indikator kejelasan strategi pencapaian tujuan, terdapat 4 butir pernyataan. Dalam indikator ini nilai persentasenya mencapai $57.00 \%$, hasil tersebut diperoleh dari skor ideal dari indikator mengetahui dan aplikasi yakni $4 \mathrm{x}$ $5 \times 59=1180$. Kemudian dibagi dengan skor rill yang diisi oleh responden yaitu sebesar $673: 1180=0.570 \times 100 \%=$ $57.00 \%$.

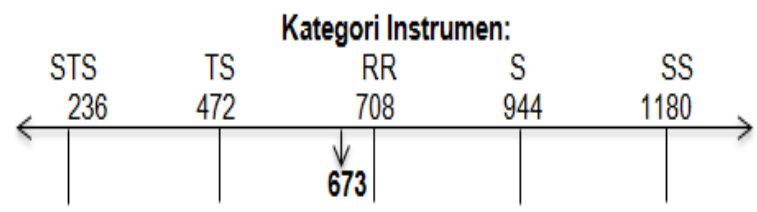

Gambar 4. Kategori Instrumen Pencapaian Tujuan
Dengan demikian, kejelasan strategi pencapaian tujuan masih berada dalam interval tidak setuju dan ragu-ragu namun untuk kategori kejelasan strategi pencapaian tujuan lebih dominan ke raguragu. Hal ini dapat terlihat dari jawaban responden terhadap pernyataan yang diberikan.

\section{Proses Analisis dan Perumusan Kebijakan}

Dalam indikator proses analisis dan perumusan kebijakan yang mantap, terdapat 3 butir pernyataan. Dalam indikator ini nilai persentasenya mencapai 55.48, hasil tersebut diperoleh dari skor ideal dari indikator mengetahui dan aplikasi yakni $3 \mathrm{x}$ $5 \times 59=885$. Kemudian dibagi dengan skor rill yang diisi oleh responden yaitu sebesar $491: 885=0.5548 \times 100 \%=55,48 \%$. Kategori instrumen indikator proses analisis dan perumusan kebijakan yang mantap:

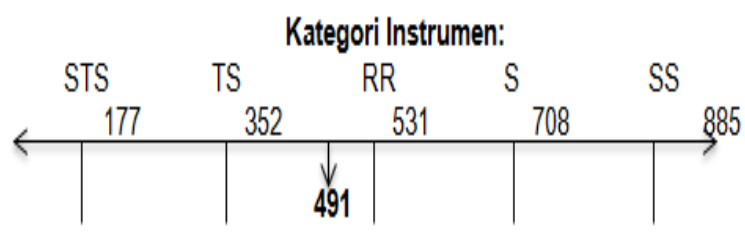

Gambar 5. Kategori Instrumen Analisis dan Perumusan Kebijakan

Dengan demikian, kejelasan strategi pencapaian tujuan masih berada dalam interval tidak setuju dan ragu-ragu namun untuk kategori proses analisis dan perumusan kebijakan yang mantap lebih dominan ke ragu-ragu. Hal ini dapat terlihat dari jawaban responden terhadap pernyataan yang diberikan.

\section{Perencanaan Matang}

Dalam indikator perencanaan matang, terdapat 3 butir pernyataan. Dalam indikator ini nilai persentasenya mencapai $54.23 \%$, hasil tersebut diperoleh dari skor ideal dari indikator mengetahui dan aplikasi yakni $3 \mathrm{x}$ $5 \times 59=885$. Kemudian dibagi dengan skor rill yang diisi oleh responden yaitu sebesar 480 : $885=0.5423 \times 100 \%=54,23 \%$. Kategori instrumen indikator Perencanaan Matang : 


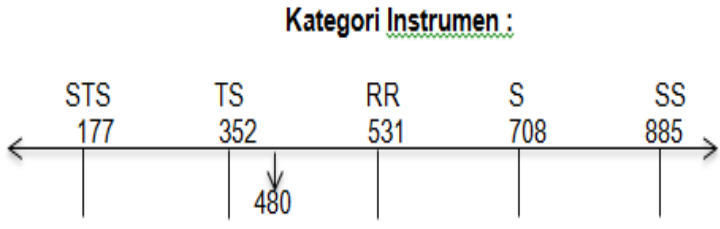

Gambar 6. Kategori Instrumen Perencanaan

Dengan demikian, perencanaan matang masih berada dalam interval tidak setuju dan ragu-ragu namun untuk kategori perencanaan matang lebih dominan ke interval tidak setuju. Hal ini dapat terlihat dari jawaban responden terhadap pernyataan yang diberikan.

\section{Penyusunan Program yang Tepat}

Dalam indikator penyusunan program yang tepat, terdapat 3 butir pernyataan. Dalam indikator ini nilai persentasenya mencapai $59,54 \%$, hasil tersebut diperoleh dari skor ideal dari indikator mengetahui dan aplikasi yakni 3 × 5 × $59=885$. Kemudian dibagi dengan skor rill yang diisi oleh responden yaitu sebesar $527: 885=$ $0.5954 \times 100 \%=59,54 \%$. Kategori instrumen indikator penyusunan program yang tepat :

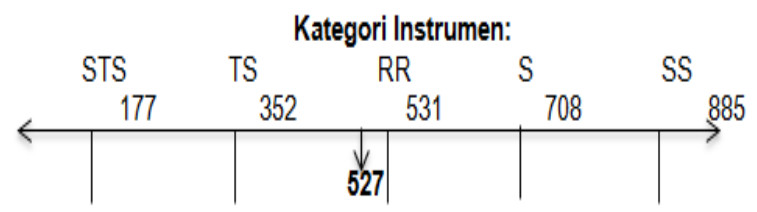

Gambar 7. Kategori Instrumen Penyusunan Program

Dengan demikian, penyusunan program yang tepat masih berada dalam interval tidak setuju dan ragu-ragu namun untuk kategori penyusunan program yang tepat lebih dominan ke interval ragu-ragu. Hal ini dapat terlihat dari jawaban responden terhadap pernyataan yang diberikan.

\section{Tersedianya Sarana dan Prasarana}

Dalam indikator tersedianya sarana dan prasarana, terdapat 4 butir pernyataan. Dalam indikator ini nilai persentasenya mencapai $56,77 \%$, hasil tersebut diperoleh dari skor ideal dari indikator mengetahui dan aplikasi yakni 4 × 5 × $59=1180$. Kemudian dibagi dengan skor rill yang diisi oleh responden yaitu sebesar $670: 1180=$ $0.5677 \times 100 \%=56,77 \%$. Kategori instrumen indikator tersedianya sarana dan prasarana :

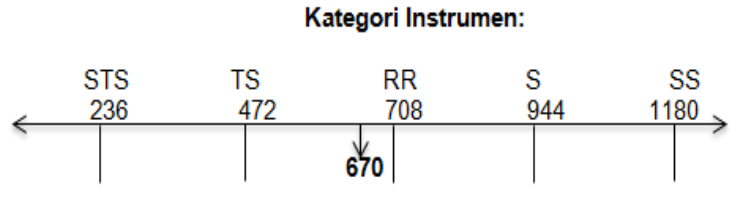

Gambar 8. Kategori Instrumen Sarana dan Prasarana

Dengan demikian, tersedianya sarana dan prasarana masih berada dalam interval tidak setuju dan ragu-ragu namun untuk kategori penyusunan program yang tepat lebih dominan ke interval ragu-ragu. Hal ini dapat terlihat dari jawaban responden terhadap pernyataan yang diberikan.

\section{Sistem Pengawasan dan Pengendalian yang Bersifat Mendidik}

Dalam indikator sistem pengawasan dan pengendalian yang bersifat mendidik, terdapat 4 butir pernyataan. Dalam indikator ini nilai persentasenya mencapai 53,98 \%, hasil tersebut diperoleh dari skor ideal dari indikator mengetahui dan aplikasi yakni $4 \mathrm{x}$ $5 \times 59=1180$. Kemudian dibagi dengan skor rill yang diisi oleh responden yaitu sebesar $637: 1180=0.5398 \times 100 \%=$ $53,98 \%$. Kategori instrumen indikator sistem pengawasan dan pengendalian yang bersifat mendidik:

\section{Kategori Instrumen:}

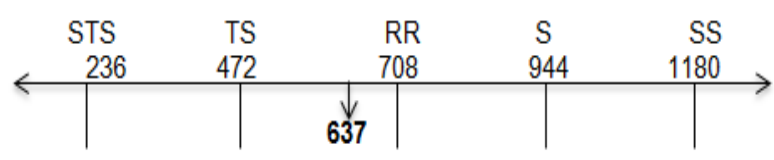

Gambar 9. Kategori Instrumen Pengawasan dan Pengendalian

Dengan demikian, sistem pengawasan dan pengendalian yang bersifat mendidik masih berada dalam interval tidak setuju dan ragu-ragu namun untuk kategori penyusunan program yang tepat lebih dominan ke interval ragu-ragu. Hal ini dapat terlihat dari jawaban responden terhadap pernyataan yang diberikan.

Berdasarkan Gambar 10, indikator paling rendah ialah indikator perencanaan matang sebesar 480 dan indikator paling tinggi yaitu sarana dan prasarana sebesar 670. Dari berbagai permasalahan dan kegiatan dari efektivitas implementasi program pemeliharaan irigasi di Kabupaten Lebak masih kurang efektif. Ditambah masih ada 
indikator yang hasilnya rendah dibandingkan dengan indikator yang lainnya yaitu indikator perencanaan matang sebesar 54,23\%. Bahwa perencanaan matang (strategi) harus dibuat dengan tepat agar supaya proses pekerjaan berjalan dengan baik.

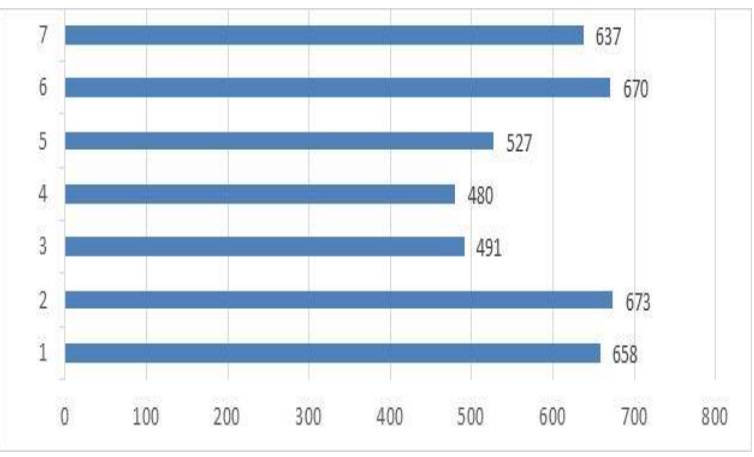

Gambar 10. Efektivitas Program

Pemeliharaan Irigasi di Dinas PUPR Kabupaten Lebak

Hasil kuesioner yang telah diolah terdapat beberapa hal yang berpengaruh pada efektivitas implementasi Program Pemeliharaan Irigasi di Kabupaten Lebak yaitu Dinas PUPR Kabupaten Lebak belum meningkatkan kualitas pemeliharaan jaringan irigasi karena masih banyak dari para responden menanggap tidak ada peningkatan dalam kualitas pemeliharaan jaringan irigasi. Salah satunya ialah karena waktu pelaksanaan pemeliharaan yang tidak dilakukan secara berkala dan dianggap telat dalam melaksanakan renovasi dan perbaikan, melainkan mendahulukan jaringan irigasi yang dianggap rusak berat sehingga mengakibatkan proses pengairan air terkendala.

\section{KESIMPULAN}

Berdasarkan dari hasil penelitian yang sudah dilakukan oleh peneliti mengenai efektivitas implementasi program pemeliharaan infrastruktur irigasi di Kabupaten Lebak, peneliti mengambil kesimpulan yaitu belum berjalan efektif karena mencapai angka 56\%, artinya angka tersebut kurang dari angka ideal yang diharapkan yaitu 65\%. Berdasarkan dari hasil yang diuji dan dianalisis oleh peneliti maka yang didapat bahwa $t_{\text {hitung }}$ jatuh pada penerimaan $\mathrm{Ho}$ dengan $\mathrm{t}_{\text {hitung }}=-0,11$ dan $t_{\text {tabel }} 0,678$ sehingga dapat diketahui bahwa $t_{\text {hitung }}$ lebih kecil dari pada $t_{\text {tabel }}$ maka Ho diterima. Hal ini karena proses pemeliharaan jaringan irigasi yang dilakukan kurang baik, rekomendasi dalam penelitian ini adalah Pemerintah Kabupaten Lebak melalui Dinas PUPR Kabupaten Lebak harus meningkatkan lagi kualitas pemeliharaan jaringan irigasi dan bisa bermanfaat sesuai dengan fungsinya, peningkatan sumber daya aparatur dan penyelesaian pemeliharaan irigasi sesuai dengan SOP dan waktu yang sudah ditentukan.

\section{DAFTAR PUSTAKA}

Alexander, D., Wilson, N., Gieseker, R., Bartlett, E., Rosseau, N. A., Amuzu, E. X., Ansong, D., Olopade, O. I., \& Olopade, C. O. 2015. Drinking Water Infrastructure in The Ashanti Region ff Ghana: Developing A Model for Sustainable Interventions by NonGovernmental Organizations. Journal of Water Sanitation and Hygiene for Development. Vol 5. No 1. 127-135 pp. https://doi.org/10.2166/washdev.2014.2 05.

Berita PUPR, Kementrian PUPR telah merehabilitasi 286 ribu hektar irigasi rusak. Selasa, 24 maret 2016. www.pu.go.id).

Ardelimas, A.R.S et al. 2016. Evaluasi Kinerja Operasi dan Pemeliharaan Sistem Irigasi Bandar Sidoras di Kecamatan Percut Sei Tuan Kabupaten Deli Serdang. Rekayasa Pangan dan Pertanian. Vol 4. No 1. 83-90 pp.

Bria, M., Muda, A.H \& Sutirto. (2017). Analisis Kriteria untuk Perencanaan Program Pemeliharaan Embung Irigasi (Studi Kasus: Embung Haliwen dan Haekrit Kabupaten Belu). Jurnal Teknik Sipil dan Perencanaan. Vol 19. No 2. 83-89 pp.

Grigg, N.S. 2019. Global Water Infrastructure: State of The Art Review. International Journal of Water Resources Development. Vol 35. No 2. 181-205 .https://doi.org/10.1080/07900627.2017 .1401919 .

Kusuma, N. \&. 2018. Analisis Dampak Rehabilitasi Jaringan Irigasi Tersier terhadap Pendapatan Petani di 
Kabupaten Aceh Besar. Journal of Chemical Information and Modeling. Vol 3. No 2.

https://doi.org/10.1017/CBO978110741 5324.004

Mollinga, P. P. 2013. Towards The Transdisciplinary Engineer. Agricultural Water Management. Vol 56. No 1. 161177pp. https://doi.org/10.1002/ird

Pasandaran, E. 2016. Pengelolaan Infrastruktur Irigasi dalam Kerangka Ketahanan Pangan Nasional. Vol 5. No 2 126-149 pp. https://doi.org/10.21082/akp.v5n2.2007. 126-149.

Peraturan Pemerintah Nomor 20 Tahun 2006 tentang Pengelolaan Jaringan Irigasi.

Peraturan Menteri Pekerjaan umum dan Perumahaan Rakyat No 12/PRT/M/2015 tentang Pedoman penyelenggaraan pemeliharaan jaringan irigasi.
Puspitasari, I. 2014. Model Alokasi Pendanaan Pemeliharaan Insfrastuktur Irigasi dengan Metode AHP (Analytic Hierarcy Process). TEDC. Vol 8. No 2. 160-170 pp.

Rafi'ud, D. A., Nurrochmad, F., \& Jayadi, R. 2017. Analisis Efisiensi Saluran Irigasi di Daerah Irigasi Boro Kabupaten Purworejo Jawa Tengah. Inersia. Vol XIII. No 2. 154-166 pp.

Rismanto, Wiyono, A., \& Wachyuni, S. 2013. Kajian Peran Serta Petani Dalam Operasi Dan Pemeliharaan Infrastruktur Jaringan Irigasi Dengan Pendekatan Theory of Planned Behaviour (Tpb) (Studi Kasus: Daerah Irigasi Cirasea Kabupaten Bandung, Jawa Barat). Jurnal Sosioteknologi. Vol 12. No 30. 502-525 pp

https://doi.org/10.5614/sostek.itbj.12.30.4

Sururi, A. 2014. Inovasi Kebijakan Publik (Tinjauan Konseptual dan Empiris). Sawala Administrasi Negara. Vol 4. No 3. $1-14 \mathrm{pp}$. 
2 Jurnal Pamator 